\title{
Pengaruh Jus Seledri (Apium graveolens L.) terhadap Gambaran Mikroskopis Hepar Tikus (Rattus norvegicus) yang Diinduksi Diet Hiperkolesterol
}

\author{
Andina Dwinanda ${ }^{1}$, Nita Afriani ${ }^{2}$, Hardisman $^{3}$
}

\begin{abstract}
Abstrak
Kadar kolesterol berlebihan dalam tubuh akan mengakibatkan penumpukan lemak di hepar. Salah satu alternatif obat tradisional yang dapat menurunkan kadar kolesterol adalah tanaman seledri. Penelitian sebelumnya menyatakan bahwa fraksi air herba seledri dapat menurunkan kadar kolesterol total pada keadaan hiperkolesterol. Tujuan penelitian ini adalah menentukan pengaruh pemberian jus seledri terhadap gambaran mikroskopis hepar yang diinduksi diet hiperkolesterol pada tikus percobaan. Jenis penelitian adalah eksperimental dengan desain post test control group. Sampel berjumlah 25 ekor tikus yang terdiri atas 5 kelompok yaitu kelompok kontrol negatif, kontrol positif, perlakuan 1, perlakuan 2 dan perlakuan 3. Masing-masing perlakuan diberikan diet hiperkolesterol yang dibuat dari minyak babi sebanyak 2 gram dan kuning telur puyuh rebus 1 gram selama 14 hari. Selanjutnya diberikan jus seledri dengan dosis masing-masing kelompok perlakuan yaitu 0,72ml/200gBB; 1,44ml/200gBB; dan $2,16 \mathrm{ml} / 200 \mathrm{gBB}$ yang diberikan dua kali sehari selama 14 hari berikutnya. Histopatologi hepar tikus diamati dengan menghitung jumlah sel yang mengalami perlemakan. Analisis data menggunakan uji one way Anova terhadap semua kelompok. Hasil analisis memperlihatkan terjadi perubahan jumlah sel berlemak yang bermakna secara statistik antara kelompok kontrol dengan ketiga kelompok perlakuan dengan nilai $p<0,05$. Simpulan penelitian ini adalah jus seledri dapat mengurangi perlemakan sel hepar akibat penumpukan lemak dengan dosis efektif yaitu $0,72 \mathrm{ml} / 200 \mathrm{gBB}$.
\end{abstract}

Kata kunci: hiperkolesterol, jus seledri, perlemakan sel hepar

\begin{abstract}
Excessive cholesterol levels in the body will occur fat accumulation in the liver. One alternative traditional medicine that can reduce cholesterol levels is celery. Previous research revealed that the fraction of celery herbal water can reduce total cholesterol levels in the hypercholesterolemia. The objective of this study was to determine the effect of celery juice on the microscopic picture of the liver induced a hyper cholesterol diet in experimental rats. This type of research was experimental with a post-test control group design. The sample consisted of twenty five rats consisting of five groups: negative control group, positive control, first treatment, second treatment and third treatment. Each treatment was given a hyper cholesterol diet made from two grams of pork oil and one gram boiled quail egg yolks for fourteen days. Furthermore, celery extract was given with a dose of each treatment group, as following $0.72 \mathrm{ml} / 200 \mathrm{gBB} ; 1.44 \mathrm{ml} / 200 \mathrm{gBB}$; and 2.16ml / 200gBB given twice a day for the next fourteen days. After the treatment was complete, the rats are dissected and their livers had been taken.Histopathology of rat liver was observed by counting the number of fatty cells. Data analysis used the one way ANOVA test for all groups. The results of the analysis showed a change in the number of fatty cells that were statistically significant between the control group and the three treatment groups with $p<0.05$. The conclusion of this study is celery juice can reduce liver cell fat due to fat accumulation with an effective dose of $0.72 \mathrm{ml} / 200 \mathrm{gBB}$.
\end{abstract}

Keywords: hypercholesterolemia, celery extract, fatty liver 
Affiliasi penulis: 1. Prodi Kedokteran Fakultas Kedokteran Universitas Andalas Padang (FK Unand, 2. Bagian Histologi FK Unand, 3. Bagian IImu Kesehatan Masyarakat FK Unand

Korespondensi: Andina Dwinanda, Email: dinadwinanda@gmail.com Telp: 081267844955

\section{PENDAHULUAN}

Kolesterol merupakan zat yang diperlukan tubuh untuk pembentukan membran sel dalam tubuh, pembentukan hormon steroid, dan menyusun garam empedu untuk pencernaan lemak. ${ }^{1} \quad$ Pada hiperkolesterolemia terjadi peningkatan kadar kolesterol total dan Low Density Lipoprotein (LDL) kolesterol serta penurunan kadar High Density Lipoprotein (HDL) kolesterol. $^{2}$

Hepar merupakan salah satu organ penting pada tubuh. Semua zat makanan akan diserap melalui hepar sebelum diedarkan ke seluruh tubuh. Zat makanan akan dimetabolisme di hepar, salah satunya adalah kolesterol. Kadar kolesterol yang berlebih di hepar akan terjadi penumpukan. Kolesterol yang masuk ke dalam hepar tidak semuanya dapat diangkut oleh lipoprotein dari aliran darah seluruh tubuh menuju hepar. Kolesterol yang berlebih tersebut akan menempel di pembuluh darah, sehingga lamakelamaan dapat menyebabkan timbulnya plak kolesterol. Kondisi tersebut akan menyebabkan pembuluh darah menjadi kaku atau tidak elastis lagi, dari yang semulanya mudah berkerut atau mudah melebar (elastis). ${ }^{3}$ Pengerasan pembuluh darah tersebut dinamakan aterosklerosis keadaan dimana pembuluh darah menjadi sempit dan aliran darah menjadi terganggu.

Hiperkolesterolemia menandakan adanya radikal bebas dalam tubuh. Peningkatan radikal bebas dalam tubuh dapat menyebabkan proses peroksidasi lipid. ${ }^{4}$ Penurunan aktivitas enzim lipoprotein lipase (LPL) yang menyebabkan terjadinya peningkatan kadar trigliserida (TG) dalam sel hepar sehingga dapat terjadi degenerasi lemak disekitar sel-sel hepar. ${ }^{5}$

Data dari American Heart Association tahun 2014 memperlihatkan prevalensi dari berat badan berlebih dan obesitas pada populasi di Amerika adalah 154.7 juta orang yang berarti $68.2 \%$ dari populasi di Amerika Serikat yang berusia lebih dari 20 tahun. Populasi dengan kadar kolesterol $\geq 240 \mathrm{mg} / \mathrm{dl}$ diperkirakan 31.9 juta orang (13.8\%) dari populasi. ${ }^{6}$
Data di Indonesia yang diambil dari Riset Kesehatan Dasar Nasional (RISKESDAS) tahun 2013 menunjukkan ada $35.9 \%$ dari penduduk Indonesia yang berusia $\geq 15$ tahun dengan kadar kolesterol abnormal (berdasarkan NCEP ATP III, dengan kadar kolesterol $\geq 200 \mathrm{mg} / \mathrm{dl}$ ) dimana perempuan lebih banyak dari laki-laki dan perkotaan lebih banyak dari di pedesaan. Data Riskesdas juga menunjukkan $15.9 \%$ populasi yang berusia $\geq 15$ tahun mempunyai proporsi LDL yang sangat tinggi ( $\geq 190 \mathrm{mg} / \mathrm{dl}), \quad 22.9 \%$ mempunyai kadar HDL yang kurang dari $40 \mathrm{mg} / \mathrm{dl}$, dan $11.9 \%$ dengan kadar trigliserid yang sangat tinggi $(\geq$ $500 \mathrm{mg} / \mathrm{dl}){ }^{7}$ Dislipidemia merupakana faktor risiko primer untuk PJK dan mungkin berperan sebelum faktor risiko utama lainnya muncul. Data epidemiologi menunjukkan bahwa hiperkolesterolemia merupakan faktor risiko untuk stroke iskemia. Penelitian sebelumnya menunjukkan bahwa untuk setiap penurunan LDL sebesar $30 \mathrm{mg} / \mathrm{dL}$ maka akan terjadi penurunan risiko relatif untuk penyakit jantung koroner sebesar $30 \%{ }^{8}$

Kadar kolesterol yang meningkat dalam darah dapat diturunkan dengan mengkonsumsi obat-obatan, salah satunya inhibitor 3 hidroksi 3 metilglutaril koenzim A (HMG-KoA) reduktase atau yang biasa dikenal dengan statin. Statin banyak digunakan masyarakat sebagai obat penurun kolesterol, namun obat ini juga mempunyai efek jika dikonsumsi dalam jangka panjang, diantaranya dapat menimbulkan myopathy/myalgia, hepatotoksitas, proteinuria karena terjadi gangguan pada renal, disfungsi ereksi, artritis, gangguan saraf seperti penurunan daya ingat, penurunan fungsi kognitif serta gangguan pada tidur. $^{9,10}$

Banyaknya efek samping dari penggunaan obat sintetis kimia dalam jangka panjang maka itu tidak sedikit masyarakat yang menggunakan alternatif pengobatan melalui penggunaan tanaman. ${ }^{4}$ Penggunaan tanaman sebagai obat tradisional sudah ada sejak lama dikenal di masyarakat Indonesia. Penggunaan tanaman sebagai obat cenderung mengalami peningkatan dengan adanya paradigma kembali ke alam (back to nature) dalam upaya mengatasi penyakit secara alami dan mencapai kesehatan yang optimal. ${ }^{11}$ Selain biaya yang dikeluarkan relatif murah dibanding dengan obat- 
obatan kimia, efek samping yang dimiliki juga jauh lebih rendah. Saat ini masih banyak masyarakat Indonesia yang memanfaatkan tanaman obat untuk mengatasi penyakit dalam meningkatkan kesehatan.

Salah satu tanaman yang dapat memberikan efek positif dalam pengobatan hiperkolestrolemia adalah seledri (Apium graveolens L.). Selain digunakan untuk penyedap makanan, tumbuhan seledri merupakan salah satu tanaman berkhasiat obat yang banyak digunakan oleh masyarakat. Seledri mengandung fitosterol yang merupakan komponen fitokimia yang berguna untuk melawan kolesterol. Selain itu, fitosterol juga berfungsi dalam mencegah penyakit jantung seperti aterosklerosis. ${ }^{12}$ Flavonoid yang juga terdapat dalam tumbuhan seledri dapat melindungi tubuh dari penyakit kardiovaskular dan beberapa penyakit kronik lainnya jika dikonsumsi secara rutin. ${ }^{13}$ Selain itu, flavonoid dapat mengurangi pengaruh radikal bebas dalam tubuh. ${ }^{14}$

Pada penelitian sebelumnya telah dilakukan pengujian terhadap pengaruh jus seledri (Apium graveolens $L$ ) terhadap kadar kolesterol total mencit putih jantan hiperkolesterol. ${ }^{15}$ Ditemukan bahwa fraksi air herba seledri dapat menurunkan kadar kolesterol total pada keadaan hiperkolesterol. Namun demikian, penelitian mengenai pengaruh jus seledri terhadap gambaran mikroskopis hepar tikus yang diberikan diet hiperkolesterol belum ada. Padahal gambaran mikroskopis mencit dengan hiperkolesterolemia terdapat gambaran susunan sel yang berubah akibat dari degenerasi lemak sehingga adanya perubahan struktur pada hepar dan tidak dapat kembali seperti keadaan semula. ${ }^{4}$

Berdasarkan hal tersebut, peneliti ingin meneliti mengenai bagaimana pengaruh pemberian jus seledri terhadap gambaran mikroskopis hepar tikus (Rattus norvegicus) yang diinduksi diet hiperkolesterol.

\section{METODE}

Penelitian ini merupakan studi eksperimental dengan post test control group design pada tikus (Rattus norvegicus) hiperkolesterol. Pemeliharaan, perlakuan, dan pengukuran berat badan hewan coba dilakukan di Animal House Fakultas kedokteran Universitas Andalas. Pembuatan sediaan preparat dilakukan di Laboratorium Patologi Anatomi Fakultas
Kedokteran Universitas Andalas dan pengamatan preparat dilakukan di Laboratorium Histologi Fakultas Kedokteran Universitas Andalas.

Populasi yang digunakan dalam penelitian ini adalah tikus (Rattus norvegicus) yang memiliki berat badan berkisar \pm 200 gram dan dalam kondisi sehat. Besar sampel minimal yang dibutuhkan dalam penelitian ini ditentukan berdasarkan kriteria World Health Organization (WHO) yaitu sebanyak lima ekor tikus untuk setiap kelompok. ${ }^{16}$ Maka total sampel yang diperlukan untuk lima kelompok adalah sebanyak 25 ekor tikus. Untuk mencegah terjadi drop out di tengah penelitian, maka koreksi besar sampel perlu dilakukan dengan perkiraan proporsi drop out sebesar $10 \%$. Maka sampel ditambah dua ekor untuk setiap kelompok. Sehingga total sampel yang dibutuhkan untuk lima kelompok adalah 35 ekor tikus.

Sampel penelitian yang dipilih adalah tikus yang memiliki kriteria inklusi dan tidak memiliki kriteria eksklusi. Kriteria inklusi subjek: Tikus (Rattus norvegicus) galur wistar jantan, berat badan berkisar \200 gram, secara makroskopis tidak ada kelainan morfologi, dan aktif bergerak. Kriteria eksklusi subjek: Tikus mati saat penelitian berlangsung dan tikus sakit, yang dicirikan oleh penampakan bulu kusam, rontok / botak, kurang / tidak aktif, keluarnya eksudat tidak normal dari mata, mulut, anus, atau genital

Pembuatan jus seledri dilakukan dengan cara 50 gram seledri yang telah di cuci dan di bersihkan kemudian potong kecil-kecil. Potongan tersebut dimasukan ke blender dan di tambahkan air aquades sebanyak $50 \mathrm{ml}$. Setelah di blender, kemudian cairan yang di hasilkan di saring menggunakan kertas saring kemudian didapatkan jus seledri. ${ }^{12}$

Diet hiperkolesterol dibuat dari minyak babi sebanyak dua $\mathrm{ml}$ dan kuning telur puyuh rebus yang telah di hancurkan sebanyak satu gram. Bahan-bahan tersebut dicampurkan dan diaduk hingga rata. Pemberian diet hiperkolesterol pada tikus dengan cara diinduksi menggunakan sonde lambung selama 14 hari.

Tahapan yang dilakukan untuk membuat preparat histologi hepar tikus adalah:

1. Jaringan hepar diambil sekitar $1 \mathrm{~mm}^{3}$ dan difiksasi dalam formalin $10 \%$ sampai terfiksasi dengan sempurna. 
2. Sampel hepar dipotong kecil dan disusun ke dalam tissue cassette. Pada tissue cassete tersebut dilakukan proses dehidrasi.

3. Proses dehidrasi dilakukan dengan alkohol berbagai kadar.

4. Sampel dijernihkan (clearing) dengan xylol dan selanjutnya dilakukan embedding menggunakan parafin yang telah dicairkan.

5. Setelah didinginkan, lilin parafin membeku membentuk blok parafin.

6. Blok parafin dipotong dengan ketebalan memotong $5 \mu \mathrm{m}$ menggunakan mikrotom.

7. Potongan tersebut dimasukkan ke dalam air hangat (waterbath) dan setelah itu dipindahkan ke atas kaca objek yang sudah diolesi ewith (albumin). ${ }^{17}$

Preparat hepar tikus diwarnai dengan metode Hematoxylin Eosin, berikut langkah-langkah pewarnaan preparat:

1. Preparat dicelupkan ke dalam xylol untuk melarutkan sisa parafin yang terdapat pada jaringan.

2. Preparat dicelupkan ke dalam alkohol berbagai kadar untuk proses rehidrasi. Lalu preparat dicuci dengan air mengalir dan dikeringkan.

3. Preparat yang sudah kering dimasukkan ke dalam larutan hematoxylin untuk pewarnaan, lalu dicuci dengan air mengalir.

4. Preparat yang sudah terwarnai hematoxylin dicelupkan ke dalam larutan pembiru dan dicuci dengan air mengalir.

5. Setelah itu preparat dicelupkan ke dalam larutan eosin untuk pewarnaan selanjutnya.

6. Preparat yang sudah terwarnai larutan hematoxylin eosin dicuci dengan air mengalir dan dimasukkan kembali ke dalam alkohol untuk dehidrasi. Lalu dicelupkan ke dalam xylol untuk clearing.

7. Selanjutnya preparat ditetesi dengan entelan, ditutup dengan cover glass dan diberi label. ${ }^{17}$

Data yang diperoleh adalah jumlah sel yang mengalami degenerasi akibat degenerasi lemak pada hepar. Data tersebut diolah secara komputerisasi. Data yang diperoleh dianalisa secara statistik dengan uji oneway Anova jika data terdistribusi normal. Jika data tidak normal, maka dilakukan dengan uji alternatif Kruskall Wallis. Untuk mengetahui adanya perbedaan yang bermakna diantara dua kelompok perlakukan dilakukan uji statistic post-hoc test.

\section{HASIL}

Penelitian ini menggunakan 35 ekor tikus (Rattus novergicus) galur wistar dengan berat badan sekitar 200 - 250 gram. Tikus-tikus tersebut di bagi ke dalam lima kelompok secara acak, sehingga masingmasing kelompok berisikan tujuh ekor tikus. Kelompok dibagi atas kelompok kontrol positif, kelompok kontrol negatif dan tiga kelompok yang diberi perlakuan setiap hari. Setelah 28 hari setelah tikus diberikan perlakuan, tikus kemudian di bedah dan diambil heparnya. Sepuluh tikus yang dipersiapkan sebagai drop out tidak di bedah, sehingga total tikus yang di bedah setiap kelompok adalah lima tikus.

Hepar yang telah diambil dari hasil pembedahan akan di simpan dalam larutan PFA dan dibuat preparat histologi dengan pewarnaan HE. Gambaran histopatologi hepar dinilai dengan cara menghitung jumlah sel yang mengalami perlemakan akibat degenerasi lemak per lapangan pandang besar. Setiap preparat dinilai sebanyak lima lapangan pandang.

\section{Gambaran Mikroskopis hepar Tikus}

Tabel 1. Jumlah perlemakan sel hepar tikus masingmasing kelompok sampel

\begin{tabular}{|c|c|c|c|c|c|c|c|}
\hline \multirow{2}{*}{ Kelompok } & \multirow{2}{*}{$\begin{array}{l}\text { Nomor } \\
\text { Sampel }\end{array}$} & \multicolumn{5}{|c|}{ Skor Perlemakan Sel Hepar } & \multirow{2}{*}{ Rata-rata } \\
\hline & & LP 1 & LP 2 & LP 3 & LP 4 & LP 5 & \\
\hline \multirow{5}{*}{ Kontrol Negatif } & 1 & 32 & 25 & 21 & 24 & 27 & 25.8 \\
\hline & 2 & 25 & 21 & 22 & 19 & 23 & 22 \\
\hline & 3 & 27 & 28 & 30 & 29 & 34 & 29.6 \\
\hline & 4 & 34 & 29 & 28 & 37 & 28 & 31.2 \\
\hline & 5 & 26 & 25 & 25 & 36 & 31 & 28.6 \\
\hline \multirow{5}{*}{ Kontrol Positif } & 1 & 77 & 67 & 88 & 88 & 90 & 82 \\
\hline & 2 & 61 & 73 & 55 & 71 & 65 & 65 \\
\hline & 3 & 67 & 68 & 70 & 74 & 83 & 72.4 \\
\hline & 4 & 61 & 74 & 91 & 74 & 59 & 71.8 \\
\hline & 5 & 51 & 45 & 48 & 53 & 57 & 50.8 \\
\hline \multirow{5}{*}{ Perlakuan 1} & 1 & 44 & 74 & 58 & 60 & 63 & 59.8 \\
\hline & 2 & 49 & 53 & 50 & 48 & 30 & 46 \\
\hline & 3 & 34 & 38 & 32 & 30 & 37 & 34.2 \\
\hline & 4 & 41 & 34 & 38 & 32 & 44 & 37.8 \\
\hline & 5 & 41 & 40 & 39 & 63 & 51 & 46.8 \\
\hline \multirow{5}{*}{ Perlakuan 2} & 1 & 31 & 37 & 29 & 21 & 42 & 32 \\
\hline & 2 & 50 & 44 & 43 & 48 & 41 & 45.2 \\
\hline & 3 & 50 & 53 & 52 & 55 & 55 & 53 \\
\hline & 4 & 35 & 53 & 42 & 40 & 42 & 42.4 \\
\hline & 5 & 42 & 47 & 49 & 54 & 84 & 55.2 \\
\hline \multirow{5}{*}{ Perlakuan 3} & 1 & 40 & 44 & 29 & 36 & 31 & 36 \\
\hline & 2 & 66 & 53 & 47 & 49 & 66 & 56.2 \\
\hline & 3 & 55 & 47 & 39 & 52 & 54 & 49.4 \\
\hline & 4 & 45 & 62 & 43 & 63 & 50 & 52.6 \\
\hline & 5 & 45 & 53 & 48 & 44 & 38 & 45.6 \\
\hline
\end{tabular}


Berdasarkan Tabel 1 dapat dilihat bahwa Jumlah perlemakan sel hepatosit yang paling banyak terdapat pada kelompok kontrol positif dibandingkan dengan empat kelompok perlakuan lainnya. Pada kelompok kontrol positif yang memiliki jumlah perlemakan sel hepatosit tertinggi terdapat pada Sampel 1, sedangkan jumlah perlemakan sel hepatosit terendah di temukan pada kelompok kontrol negatif Sampel 2.

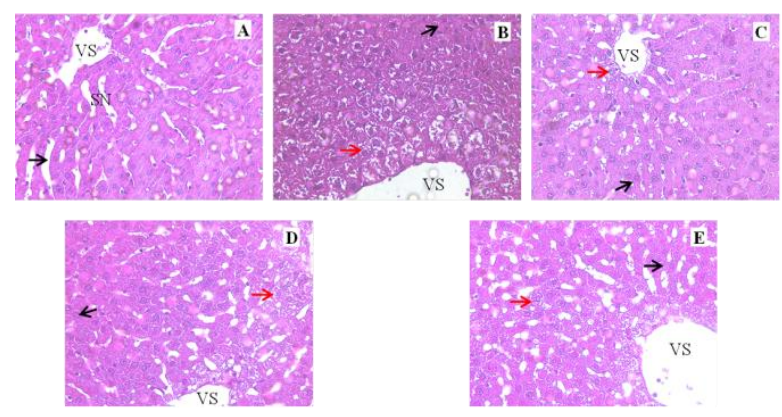

Gambar 1. Distribusi frekuensi penderita sindroma dispepsia berdasarkan derajat dispepsia

Keterangan : A. kontrol negatif (tanpa diet hiperkolesterol), B. Kontrol positif (hanya diet hiperkolesterol, C. Perlakuan 1 (diet hiperkolesterol dan jus seledri $0,72 \mathrm{ml} / 200 \mathrm{gBB}$ ), D. Perlakuan 2 (diet hiperkolesterol dan jus seledri 1,44ml/200gBB), E. Perlakuan 3 (diet hiperkolesterol dan jus seledri $2,16 \mathrm{ml} / 200 \mathrm{gBB})$, VS. Vena sentralis, SN. Sinusoid, panah hitam : sel normal, panah merah : sel yang mengalami perlemakan.

Jaringan hepar tikus pada kelompok kontrol negatif pada gambar 1 (A) menunjukan gambaran histologi normal. Gambaran beberapa sel hepar yang dekat vena sentralis membentuk lempeng yang tersusun radier serta sinusoid masih tampak jelas. ${ }^{21}$ Jaringan hepar tikus pada kelompok kontrol positif (B) di sekitar sel hepar dekat vena sentralis mengalami pembengkakan akibat degenerasi lemak dan sinusoid tampak tidak teratur, begitupula pada kelompok perlakuan $1(\mathrm{C})$, perlakuan 2 (D) dan perlakuan $3(\mathrm{E})$ namun sinusoid sudah mulai kembali mendekati normal. Perlemakan yang terjadi ditandai dengan adanya vakuola jernih dalam sitoplasma.

\section{Perbedaan Gambaran Mikroskopis Hepar Tikus}

Data perlemakan sel hepar setiap kelompok sampel yang didapat dilakukan uji normalitas terlebih dahulu dengan menggunakan uji Kolmogorov-Smirnov Test untuk mengetahui apakah data tersebut terdistribusi normal atau tidak. Sampel terdistribusi normal apabila nilai kemaknaan p>0,05. Setelah dilakukan uji Kolmogorov-Smirnov Test didapatkan bahwa data tersebut memiliki kemaknaan $=0,200$ yang berarti terdistribusi normal.

Dilakukan uji one way ANOVA untuk mengatahui adanya perbedaan rata-rata antara lebih dari dua kelompok sampel. Hasil analisis uji one way ANOVA ada perbedaan bermakna terhadap jumlah perlemakan sel hepar antar kelompok sampel dengan nilai $p=0,001$, yang berarti terdapat perbedaan yang signifikan antara pemberian jus seledri terhadap gambaran mikroskopis hepar tikus yang diet hiperkolesterol.

Tabel 2. Jumlah perlemakan sel hepar tikus

\begin{tabular}{|c|c|c|}
\hline Kelompok & Rata-rata \pm SD & $p$ \\
\hline Kontrol negatif & $27.44 \pm 3.62$ & \\
\hline Kontrol positif & $68.40 \pm 11.55$ & \\
\hline Perlakuan 1 & $44.92 \pm 9.89$ & 0,001 \\
\hline Perlakuan 2 & $45.56 \pm 9.25$ & \\
\hline Perlakuan 3 & $47.96 \pm 7.74$ & \\
\hline
\end{tabular}

Berdasarkan Tabel 2 dapat dilihat bahwa Jumlah perlemakan pada sel hepar yang didapatkan pada kelompok kontrol negatif merupakan kelompok dengan rata-rata yang paling sedikit, yaitu 27,44 dengan standar defiasi 2,62, sedangkan kelompok yang memiliki rata-rata perlemakan sel hepar yang paling banyak terdapat pada kelompok komtrol negatif dengan rata-rata 68,4 dengan standar defiasi 11,55. Pada kelompok perlakuan 1, kelompok perlakuan 2, dan kelompok perlakuan 3 terdapat penurunan jumlah rata-rata perlemakan pada hepar apabila dibandingkan dengan kelompok kontrol positif. 
Tabel 3. Perbedaan jumlah perlemakan sel hepar tikus antar dua kelompok

\begin{tabular}{|c|c|c|c|}
\hline Perlakuan & Perlakuan & $p$ & Kemaknaan \\
\hline \multirow{4}{*}{ Kontrol negatif } & Kontrol positif & 0.001 & Signifikan \\
\hline & Perlakuan 1 & 0.005 & Signifikan \\
\hline & Perlakuan 2 & 0.004 & Signifikan \\
\hline & Perlakuan 3 & 0.002 & Signifikan \\
\hline \multirow{4}{*}{ Kontrol positif } & Kontrol negatif & 0.001 & Signifikan \\
\hline & Perlakuan 1 & 0.001 & Signifikan \\
\hline & Perlakuan 2 & 0.001 & Signifikan \\
\hline & Perlakuan 3 & 0.002 & Signifikan \\
\hline \multirow{4}{*}{ Perlakuan 1} & Kontrol negatif & 0.005 & Signifikan \\
\hline & Kontrol positif & 0.001 & Signifikan \\
\hline & Perlakuan 2 & 0.91 & Tidak Signifikan \\
\hline & Perlakuan 3 & 0.592 & Tidak Signifikan \\
\hline \multirow{4}{*}{ Perlakuan 2} & Kontrol negatif & 0.004 & Signifikan \\
\hline & Kontrol positif & 0.001 & Signifikan \\
\hline & Perlakuan 1 & 0.91 & Tidak Signifikan \\
\hline & Perlakuan 3 & 0.672 & Tidak Signifikan \\
\hline \multirow{4}{*}{ Perlakuan 3} & Kontrol negatif & 0.002 & Signifikan \\
\hline & Kontrol positif & 0.002 & Signifikan \\
\hline & Perlakuan 1 & 0.592 & Tidak Signifikan \\
\hline & Perlakuan 2 & 0.672 & Tidak Signifikan \\
\hline
\end{tabular}

Pada tabel 3 menunjukan hasil uji Post Hoc test yaitu untuk menilai berbedaan antara 2 kelompok. Hasil uji Post Hoc test ditemukan ada perbedaan yang bermakna terhadap jumlah perlemakan sel hepar dengan nilai $p<0,05$ yaitu antara kelompok kontrol negatif dengan kelompok kontrol positif, kelompok kontrol negatif dengan kelompok perlakuan 1, kelompok kontrol negatif dengan kelompok perlakuan perlakuan 2 dan kelompok kontrol negatif dengan kelompok perlakuan perlakuan 3. Pada kelompok kontrol positif juga menunjukan perbadaan yang bermakna terhadap kelompok perlakuan 1, dengan kelompok perlakuan 2, dan dengan kelompok perlakuan 3. Namun juga ditemukan nilai kemaknaan p>0,05 yang artinya tidak ada perbedaan yang bermakna antara kelompok perlakuan 1 dengan kelompok perlakuan 2, kelompok perlakuan 2 dengan kelompok perlakuan 3 , serta kelompok perlakuan 1 dengan perlakuan 3 .

\section{PEMBAHASAN}

Berdasarkan pengamatan histopatologi sel hepar didapatkan bahwa rata-rata perlemakan sel hepar pada kelompok kontrol negatif 27,44 dengan standar deviasi 3,62, sedangkan pada kelompok kontrol positif terlihat lebih banyak kerusakan yaitu
68,40 dengan standar deviasi 11,55. Rata-rata perlemakan sel hepar pada kelompok yang diberi perlakuan jus seledri $0,72 \mathrm{ml} / 200 \mathrm{gBB}$ (perlakuan 1) mulai menurun menjadi 44,92 dengan standar deviasi 9,89 , sedangkan pada kelompok yang diberi perlakuan jus seledri 1,44ml/200gBB (perlakuan 2) dan $2,16 \mathrm{ml} / 200 \mathrm{gBB}$ (perlakuan 3) masing-masingnya adalah 45,56 dengan standar deviasi 9,25 dan 47,96 dengan standar deviasi 7,74.

Perbedaan rata-rata antara kelompok kontrol positif dengan perlakuan menunjukan bahwa jus seledri dapat mengurangi perlemakan sel hepar pada tikus. Hal ini ditandai dengan gambaran sel hepatosit yang rusak lebih sedikit pada kelompok yang diberi perlakuan dibandingkan dengan kelompok kontrol positif namun penelitian ini belum menjelaskan bagaimana perbaikan yang terjadi terhadap sinusoid hepar.

Perbaikan gambaran histopatologi yang terjadi pada hepar kelompok perlakuan dapat terjadi karena adanya kerja antioksidan. Senyawa anti oksidan tersebut juga dapat menurunkan kadar trigliserida dalam darah dengan meningkatkan aktivitas enzim LPL. Apabila aktifitas enzim LPL meningkat, maka LPL dapat mengubah VLDL menjadi IDL, sehingga akumulasi VLDL dalam hepar akan berkurang dan. ${ }^{18}$

Berdasarkan hasil analisis dengan Post Hoc test menyimpulkan bahwa tidak ada perbedaan yang bermakna antara kelompok perlakuan 1 dengan 2, kelompok perlakuan 1 dengan 3 , maupun antara kelompok perlakuan 2 dengan 3. Maka dapat disimpulkan bahwa pada kelompok perlakuan 1 yang diberi jus seledri dengan dosis terendah yaitu 0,72ml/200gBB atau setara dengan 40,32ml/70 kgBB pada manusia, cukup untuk memperbaiki sel hepar yang rusak akibat degenerasi lemak dari pada menggunakan jus seledri dengan dosis yang lebih tinggi yaitu $1,44 \mathrm{ml} / 200 \mathrm{gBB}$ atau $2,16 \mathrm{ml} / 200 \mathrm{gBB}$. Hal ini sesuai dengan penelitian yang telah dilakukan sebelumnya yang mengatakan bahwa dosis efektif jus seledri adalah $0,072 \mathrm{ml} / 200 \mathrm{gBB} .^{12}$

Pada percobaan ini menunjukan adanya rasio yang bervariasi pada tiap tikus kelompok perlakuan yang melewati prosedur yang sama. Hal ini dapat terjadi karena variasi individu yang dipengaruhi oleh adanya variabel lain yang tidak bisa dikontrol selama 
adaptasi dan pemberian perlakuan hewan coba di Animal House, antara lain variasi dari kepekaan terhadap zat yang diberikan, faktor hormonal, faktor lingkungan seperti stres, dan faktor lainnya.sebagai contoh, pada kelompok perlakuan kontrol negatif yang tidak diberi apa-apa masih terdapat perlemakan sel. $\mathrm{Hal}$ ini mungkin dapat terjadi karena kandungan lemakn yang terdapat pada pakan yang diberikan. Selain itu, seledri yang digunakan juga tidak diketahui zat lain yang terdapat di dalamnya seperti adanya pestisida yang digunakan selama penanaman, lama penanaman seledri, dan lain sebagainya.

Penelitian ini tidak dapat menilai bagaimana gambaran sel hepar sebelum di berikan perlakuan (pre-test) pada masing-masing hewan coba, sehingga dari hasil penilaian belum tentu semua perlemakan yang terjadi pada sel hepar murni akibat perlakuan yang diberikan, maka dari itu adanya kontrol negatif sebagai pembanding. Pengamatan preparat dilakukan oleh peneliti dan hanya dibimbing oleh dosen histologi. Kemudian karena tidak adanya batasan yang jelas antara sel yang mengalami degenerasi dengan sel yang normal, tetap ada unsur subjektif dalam menghitung perlemakan sel hepar tikus pada preparat yang diamati.

\section{SIMPULAN}

Pada gambaran mikroskopis hepar tikus (Rattus norvegicus) yang diinduksi diet hiperkolesterol menunjukan jaringan disekitar sel hepar dekat vena sentralis mengalami perlemakan dan sinusoid tampak tidak teratur, sedangkan pada gambaran mikroskopis hepar tikus (Rattus norvegicus) yang diinduksi diet hiperkolesterol sesudah pemberian jus seledri menunjukan terjadinya penurunan jumlah perlemakan sel hepar akibat jika dibandingkan dengan kelompok kontrol positi. Namun, tidak terdapat perbedaan yang bermakna antar gambaran histopatologi hepar tikus (Rattus norvegicus) perlakuan baik yang diberi dosis jus seledri $0,72 \mathrm{ml} / 200 \mathrm{gBB} ; 1,44 \mathrm{ml} / 200 \mathrm{gBB}$ maupun 2,16ml/200gBB; sehingga dapat ditentukan dosis efektif jus seledri untuk mengurangi perlemakan pada sel hepar yaitu dengan dosis terkecil pada penelitian ini $(0,72 \mathrm{ml} / 200 \mathrm{gBB})$.

\section{DAFTAR PUSTAKA}

1. Suwarso E, Anggraeni DN. Efek infus daun seledri (Apium graviolens I.) terhadap kadar kolesterol. Prosiding Seminar Nasional Biologi dan Pembelajarannya. Medan: 23 Agustus 2014. hlm.302-7.

2. Tjandra A, Ridwan A, Kodariah L. Ekstrak etanol seledri (Apium graveolens) sebagai antiatherogenik pada tikus (Rattus norvegicus) yang diinduksi hiperlipidemia. Prosiding Symbion (Symposium on Biology Education). Bandung: 2016.hlm.171-88.

3. Botham KM, Mayes PA. Sintesis, transpor dan ekskresi kolesterol. Dalam: Murray RK, Bender DA, Botham KM, Kinnelly PJ, Rodwell VW, Weil PA, editor (penyunting). Pendit BU, penerjemah. Biokimia Harper. Edisi ke-29. Jakarta: Penerbit Buku Kedokteran EGC; 2014.hlm..279-90.

4. Wulandari DI, Padaga MC, Herawati. Kadar malondialdehida (MDA) dan gambaran histopatologi organ hati pada hewan model tikus (Rattus norvegicus) hiperkolesterolemia setelah terapi ekstrak air benalu mangga (Dendrophthoe pentandra L. Miq) [skripsi]. Malang: Fakultas Kedokteran Hewan Universitas Brawijaya; 2014.

5. Roslizawaty J, Rusli, Nazaruddin, Syarifuddin, Bangun IS. Peningkatan aktivitas enzim lipoprotein lipase (LPL) dan perubahan histopatologis hati Tikur (Rattus norvegicus) hiperkolesterolemia yang diberi ekstrak sarang semut (Myrmecodia sp.). Jurnal Kedokteran Hewan. 2016;10(1):77-81.

6. Mozzaffarian D, Roger VL. Heart Disease and Stroke Statistic. Dalam: Arsana PM, Rosandi R, Manaf A, Budhiarta AAG, Permana H, Sucipta KW, et al, editor (penyunting). PERKENI. Paduan pengelolaan dislipidemia di Indonesia - 2015. Jakarta: PB. PERKENI; 2015.hlm.4-7.

7. Badan Penelitian dan Pengembangan Kesehatan Kementrian RI tahun 2013. Laporan nasional riset kesehatan dasar (Riskesdas) 2013. Dalam: Arsana PM, Rosandi R, Manaf A, Budhiarta AAG, Permana $\mathrm{H}$, Sucipta $\mathrm{KW}$, et al, editor (penyunting). PERKENI. Paduan pengelolaan dislipidemia di Indonesia-2015. Jakarta: PB PERKENI; 2015:4-7. 
8. Grundy SM, Ji Cleeman, Merz CN. Implications of recent clinical trials for the national cholesterol education program adult treatment panel III guidelines circulation. 2004;110:227-39.

9. Sinzinger H, Peskar BA. 2009. Dalam: Rosita I, Andrajati R, Zainuddin. Efek samping nyeri otot simvastatin dan atrovastatin pada pasien jantung RSUD Tarakan [skripsi]. Jakarta: Fakultas Farmasi Universitas Indonesia; 2014. hlm.1-20.

10. Mariam, Paul MK, Vasa C, Azeem M. Dalam: Efek samping nyeri otot simvastatin dan atrovastatin pada pasien jantung RSUD Tarakan. Jakarta: Fakultas Farmasi Universitas Indonesia; 2014.hlm.1-20.

11. Wijayakusuma $\mathrm{H}$. Penyembuhan dengan tanaman obat. Jakarta: PT Elex Media Komputindo Kelompok Gramedia; 1999.hlm.9.

12. Setiawan S. Pengaruh air perasan herba seledri (Apium graveolens L) terhadap kadar toral darah tikus putih (Rattus norvegicus) [skripsi]. Surakarta: Fakultas Kedokteran Universitas Sebelas Maret; 2010.

13. Knekt $P$, Kumpulainen J, Jarvinen R, Rissanen $H$, Heliovaara M, Reunanen A, et al. Flavonoid intake and risk of chronic. The American Journal of Clinical Nutrition. 2002;76(3):560-8.

14. Jawi M, Budiasa K. Ekstrak air umbi ubi jalar ungu menurunkan total kolesterol serta meningkatkan total antioksidan darah kelinci. Jurnal Veteriner. 2011;12(2):120-5.

15. Fahrefi M. Pengaruh fraksi air herba seledri (Apium graveolens L.) terhadap kadar kolesterol total mencit putih jantan hiperkolesterol [skripsi]. Padang: Fakultas Farmasi Universitas Andalas. 2013.

16. World Health Organization (WHO). General Guidelines for Methodologies on Research and Evaluation Of Traditional Medicine. 2000.hlm28-31

17. Mulyono A, Ristiyanto, Soesanti HN. Karakteristik histopatologi hepar tikus got Rattus novergicus infektif Leptospira Sp. Juarnal Vektora. 2009; 1(2): 84-92.

18. Arauna Y, Aulanni'am, Oktavianie DA. Studi kadar trigliserida dan gambaran histopatologi hepar hewan model tikus (Rattus novergicus) huperkolesterolemia yang diterapi dengan ekstrak air benalu mangga (Dendrophthoe Petandra) [skripsi]. Malang: Fakultas Kedokteran Hewan Universitas Brawijaya. 2016. 